\title{
The fish fauna of Bukit Timah Nature Reserve, Singapore
}

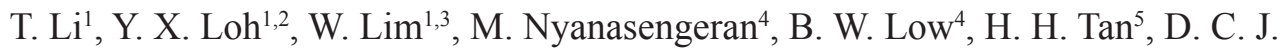 \\ $\mathrm{Yeo}^{4} \&$ Y. Cai ${ }^{1}$
}
${ }^{1}$ National Biodiversity Centre, National Parks Board, 1 Cluny Road, 259569 Singapore cai_yixiong@nparks.gov.sg
${ }^{2}$ School of Biological Sciences, Nanyang Technological University, 60 Nanyang Drive, 637551 Singapore
${ }^{3}$ Current address: Singapore Botanic Gardens, National Parks Board, 1 Cluny Road, 259569 Singapore
${ }^{4}$ Department of Biological Sciences, National University of Singapore, 14 Science Drive 4, 117543 Singapore
${ }^{5}$ Lee Kong Chian Natural History Museum, 2 Conservatory Drive, National University of Singapore, 117377 Singapore

\begin{abstract}
Bukit Timah Nature Reserve (BTNR) holds the largest remnant patch of primary rainforest in Singapore and its hill streams supports many native and threatened freshwater fauna. As the last comprehensive survey of freshwater fishes in BTNR was published nearly two decades ago, a series of surveys was carried out at 12 streams permeating BTNR and the Singapore Quarry to update the status of the fishes. Of the 27 species documented, 16 are native to Singapore and 11 are introduced. Two native species known from other parts of the Central Catchment Nature Reserve are recorded for the first time in BTNR. Species distribution, richness and abundance have been qualitatively assessed in relation to habitat characteristics. Potential threats and mitigation measures are discussed, which are important in the formulation of conservation and management strategies to safeguard the current diversity of freshwater fishes, many of which are threatened in rapidly developing Singapore.
\end{abstract}

Keywords. Conservation, freshwater, hill streams, introduced species, native, quarry

\section{Introduction}

The comprehensive biodiversity survey of the 163 ha Bukit Timah Nature Reserve (BTNR) has been introduced by Chan \& Davison (2019). The relatively less disturbed forest hill streams in the reserve support a large proportion of native and threatened freshwater fauna in Singapore, including two endemic crab species, Irmengardia johnsoni (Johnson's freshwater crab), Johora singaporensis (Singapore freshwater crab), and the nationally critically endangered Nandus nebulosus (Sunda leaf fish) and Channa gachua (Dwarf snakehead). Over the last two decades, urban and housing developments around the nature reserve, and environmental control measures, have altered the hill stream conditions in BTNR, which might have significant impacts on the aquatic biodiversity. Information on the freshwater fish species found in BTNR has not been updated since the last extensive survey done between 1996 and 1997, except 
for a new record of the introduced Osphronemus laticlavius (Red giant gouramy) in Singapore Quarry (Lim, 2013a) and the native Channa melasoma (Black snakehead) in the Catchment Pond at the eastern side of BTNR (Baker, 2014). Tan et al. (2017) have investigated the freshwater fauna of the adjacent Singapore Quarry (SQ). The objective of this study is to provide an update on the status of freshwater fish in the hill streams in BTNR, identify current and potential threats to the freshwater habitats in this area, and to recommend follow-up actions for freshwater biodiversity conservation and management based on the updated data.

\section{Materials and Methods}

\section{Study site}

A total of 12 distinct streams and ponds permeate BTNR, together with two exquarries on the western (Singapore Quarry) and south-western sides (Hindhede Quarry). Of the 12 streams visited, eight are within the boundary of the nature reserve, and six of these were surveyed intensively both temporally (repeat occasions) and spatially (through a series of transects) during the course of the study (Fig. 1). Individual descriptions of the six main stream sampling sites are provided below. The majority of the streams are situated on hill slopes with varying gradients, the lower reaches being concretised following development works on the periphery of the reserve. The streams are typically short and shallow with clear, moderately fast flowing waters and considerable canopy coverage (Chua et al., 2015).

Stream 1 is located on the south-western side of BTNR with a sandy substratum and moderate flow. The bank vegetation consists mainly of ferns, palms, bamboos and shrubs. Stream 2 is located on the south-eastern side of BTNR and is characterised by a muddy streambed and slow flowing water. Abundant vegetation and trees along the stream contribute to a large amount of leaf litter, fallen twigs and root structures along the banks. Stream 3 is on the eastern side of BTNR and its lower reach widens to form a pond. It is characterised by soft sediments on the streambed and slow flowing water, with a single outflow from the pond that cascades into a small pool, which then flows eastwards out of the reserve as a diffuse swampy outflow. Stream 4 is located on the north-western side of BTNR, where three low head dams built across the stream line cause the accumulation of water upstream forming bogs. The lower part of this hill stream, where survey sampling was conducted, is characterised by a soft and muddy streambed, shallow slow flowing water, and an abundance of leaf litter. Stream 5 is very close to Stream 4 (northwest of Stream 4) with a bridge across the stream causing some accumulation of water and consequently formation of a bog at the lower reach area. It is characterised by a deep, loamy streambed with a muddy substratum. Stream 6 is at the southern tip of BTNR where it drains into a pond at the base of the hill. This pond is characterised by a soft and muddy substratum which gets progressively deeper towards the centre with a slow water flow. It is surrounded by a moderately dense canopy cover (Fig. 2). 


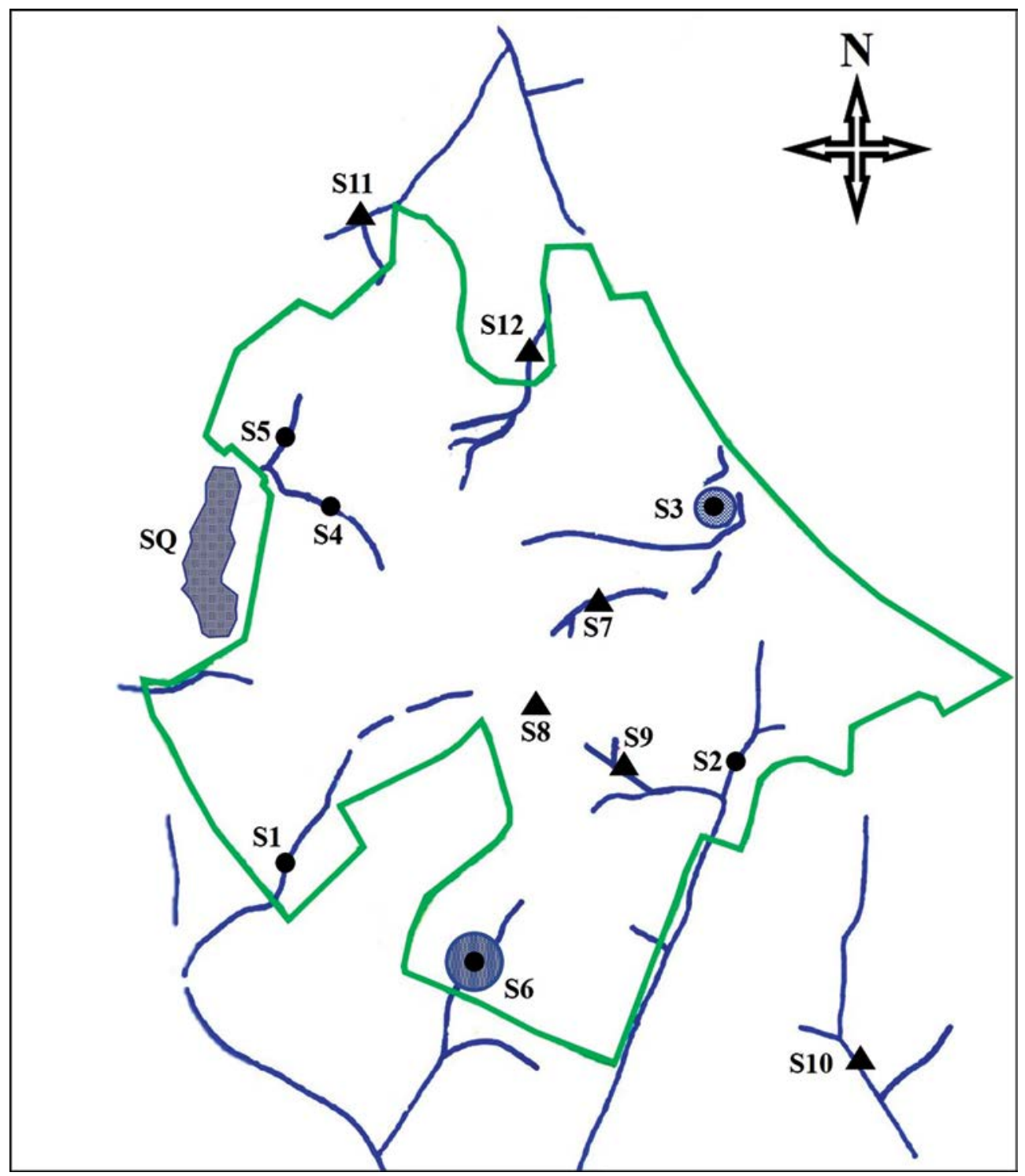

Fig. 1. Map of streams in BTNR and surrounding areas. Green line indicates boundary of the nature reserve. Blue lines indicate streams. Waterbodies sampled repeatedly over the course of the study are indicated by black circles S1-S6. Waterbodies sampled only once are indicated by black triangles S7-S12. Blue circles represent ponds. SQ represents Singapore Quarry.

The remaining six streams (Streams 7 to 12 ) and the Singapore Quarry (SQ) (Fig. 1) were also surveyed to increase the coverage of the study. However, these were one-off surveys that did not involve multiple samplings. As such, data collected from these sites were only used in distribution analysis and the compilation of checklists. Quantitative analysis of species abundance and richness were only performed using 
records from the six main sampling sites. For disambiguation, data used to compute analysis for Stream 3 and Stream 6 were collected from the ponds draining these two streams, instead of from stream segments.

\section{Sampling methods}

Seven cycles of surveys were conducted at Streams 1 to 6 in February, March, July, December 2015 and April 2016. At each stream/pond, one transect of $10 \mathrm{~m}$ was surveyed and water parameters were taken at three points within the transect.

Both push/tray net sampling by hand and minnow/bottle traps were used in the fish surveys. Push/tray net sampling involved repetitive sweeping motion against the banks with a tray net $(60 \times 40 \mathrm{~cm}$, mesh size $4 \mathrm{~mm})$, starting from a downstream to upstream direction along a stretch of $10 \mathrm{~m}$ in the designated sampling site. Banks and vegetation at the stream edge were swept using a sampling net up to 30 minutes at each site and animals caught were kept in a transparent plastic bag containing stream water for measurement and identification.

Three plastic minnow traps were used for the trap sampling at each site. A $2 \mathrm{~kg}$ metal weight was secured to each trap using cable ties to ensure that traps were fully submerged in water, with openings facing downstream. A mixture of fresh pig liver and fresh Yellowstripe scad (Selaroides leptolepis) was used as bait in the traps and traps were retrieved the next day.

In addition, for Singapore Quarry, cast nets (4 m, mesh size $2.5 \mathrm{~cm})$ and gill nets $(10 \mathrm{~m}$, mesh size $5 \mathrm{~cm})$ were used to capture fish from the deeper areas and the edges were sampled via tray nets.

All fishes were identified to species level and their standard length was measured using digital vernier calipers before being released at their original site. Stream dimensions such as wetted width were measured, while water quality parameters including depth, $\mathrm{pH}$ and dissolved oxygen were recorded using a HANNA 9829 Multiparameter at each site.

\section{Results}

Comparison with records from the previous surveys

A total of 27 freshwater fish species were recorded from this study (Table 1), including 16 native and 11 introduced species. The black snakehead Channa melasoma, slender walking catfish Clarias nieuhofii (Fig. 3A) and Sunda leaf-fish Nandus nebulosus (Fig. 3B) are listed in the Singapore Red Data Book as critically endangered (Lim et al., 2008). Clarias nieuhofii is typically a peat swamp fish and its presence in BTNR might be attributed to factors described in the discussions below. Six of the introduced species, Gambusia affinis, Poecilia reticulata, Poecilia sphenops, Puntigrus tetrazona, Rasbora trilineata, and Xiphophorus maculatus were found to be restricted to the southern and eastern outskirts of BTNR. Rasbora trilineata and Puntigrus tetrazona were only found in the pond draining Stream 3. The other five introduced species, Mayaheros urophthalmum, Clarias gariepinus, 


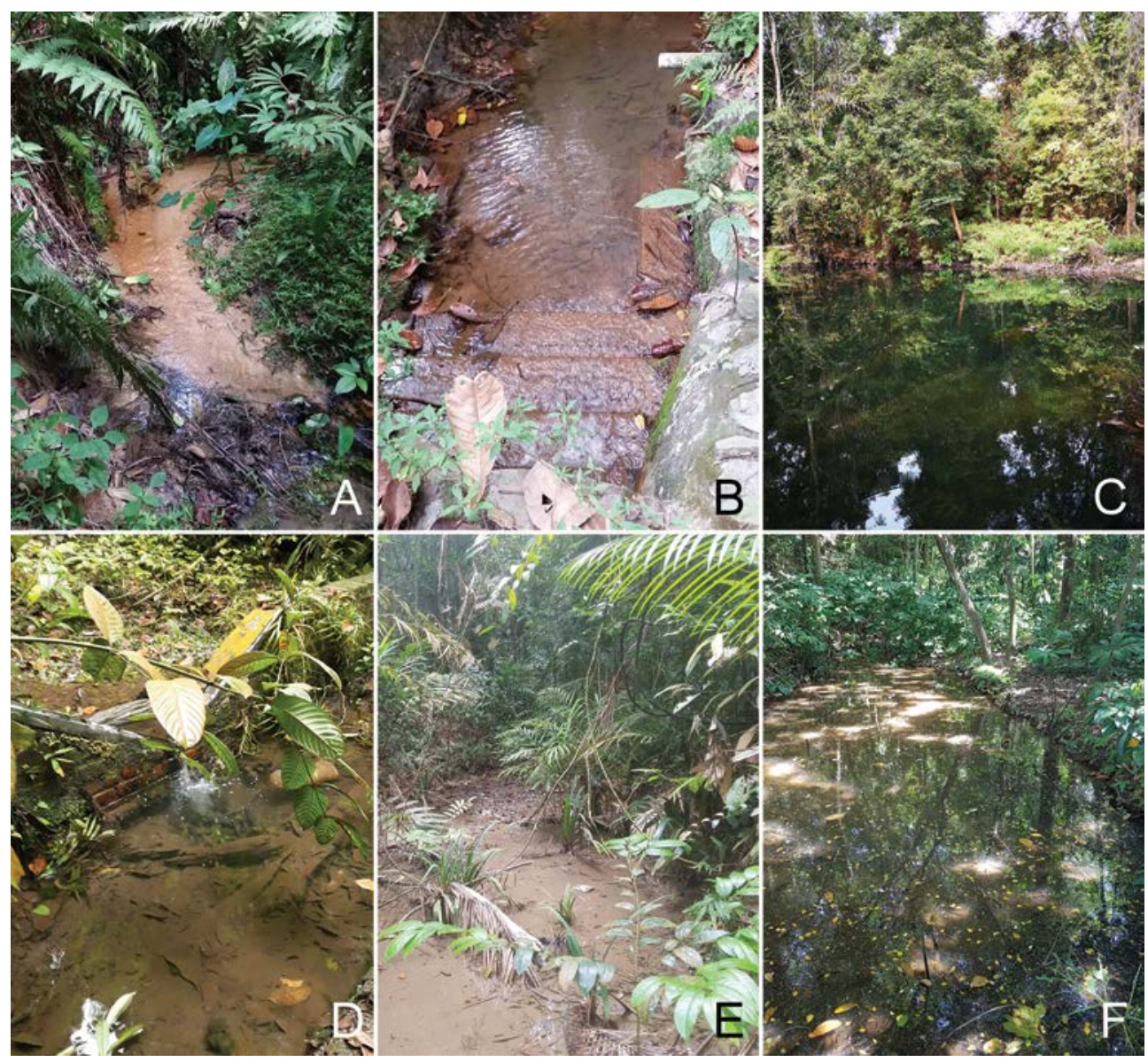

Fig. 2. Photos of stream sites. A. Stream 1. B. Stream 2. C. Stream 3 showing downstream pond. D. Stream 4 showing low head dam. E. Stream 5. F. Stream 6 showing downstream pond. (Photos: A-D \& F, T.J. Li; E, M. Khoo)

Cyprinus carpio, Oreochromis mossambicus, and Osphronemus laticlavius, were only recorded from the Singapore Quarry.

A comparison was made between the last survey ( $\mathrm{Ng} \& \mathrm{Lim}, 1997)$ and the current study. While the total number of species increased from 19 (17 native, 2 introduced) to 31, four fishes documented previously were not encountered in this study. These species are Rasbora einthovenii, Dermogenys collettei, Anabas testudineus and Channa gachua. Ten species from the current study were not previously recorded from BTNR, of which two are native (Clarias batrachus, Clarias nieuhofii) and eight are introduced (viz. Clarias gariepinus, Cyprinus carpio, Rasbora trilineata, Gambusia affinis, Poecilia sphenops, Xiphophorus maculatus, Mayaheros urophthalmum and Oreochromis mossambicus). Osphronemus laticlavius was 
recorded from Singapore Quarry in 2010 (Lim, 2013a) and Channa melasoma was recorded in the pond at the eastern side of BTNR in 2014 by Baker.

Betta pugnax was identified as having the widest distribution within BTNR, being found at all six streams/ponds surveyed (Table 2). This was also the most abundant native fish species with an average of more than 10 individuals per sampling session. The critically endangered Nandus nebulosus was only recorded from the pond draining Stream 3 and Clarias nieuhofi was recorded once at Stream 2 throughout the survey. The pond at Stream 3 was also the only site where Rasbora elegans, Aplocheilus armatus, Trichopsis vittata and Channa lucius were recorded. Betta pugnax was the only species recorded at Streams 4 and 5 throughout the study period. Most of the species were localised and present in less than three sites. The second most abundant native species was Barbodes banksi ( $>5$ individuals captured per sampling session). Of the six introduced species, Puntigrus tetrazona and Rasbora trilineata were localised to the pond draining Stream 3 in large numbers, while Poecilia sphenops and Xiphophorus maculatus were restricted to the pond draining Stream 6 at the periphery of the reserve. Gambusia affinis and Poecilia reticulata appear to be more widely distributed in Streams 1, 2 and 6. With the exception of Poecilia sphenops, all the introduced species were observed in large numbers $(>15$ individuals per sampling session) at localised sites.

At the additional sampling sites (Streams 7 to 12 and Singapore Quarry), the introduced Poecilia reticulata was the only species recorded from more than three sites (Table 3). Most sites had fewer than three species except for Singapore Quarry, from which ten species were recorded, including four native species (Barbodes lateristrigai, Oxyeleotris marmorata, Trichopodus trichopterus, Channa striata), and six introduced species (Clarias gariepinus, Cyprinus carpio, Osphronemus laticlavius, Gambusia affinis, Mayaheros urophthalmum, Oreochromis mossambicus).

\section{Species richness}

The pond draining Stream 3 had the highest species richness with a total number of 11 species, of which nine were native and two were introduced. Otherwise, species richness was generally low (three or fewer native species) for all the streams surveyed (Fig. 4). Both streams 4 and 5 had only one fish species, Betta pugnax, throughout the study period. Although the species richness was very low for Streams 4 and 5, these sites were also free from introduced species. It is also interesting to note that there were more introduced species (four species) recorded from the pond draining Stream 6 compared to native species (two species).

\section{Water parameters}

Stream 4 and Stream 5 had the lowest mean pH among all the sites surveyed, with Stream 4 being the most acidic at 4.28 , followed by Stream 5 at 4.78 (Table 4). These two streams were in close proximity and previously connected to each other on a hill slope at their downstream segments. The mean dissolved oxygen level was the lowest at the pond draining Stream 6, which also had the highest mean turbidity. Mean temperature was fairly consistent across all six main sampling sites. 
Table 1. List of freshwater fish species in Bukit Timah Nature Reserve. LC: Least Concern, NT: Near-Threatened, CR: Critically endangered.

\begin{tabular}{|c|c|c|c|c|}
\hline No. & $\begin{array}{l}\text { Local } \\
\text { Status }^{1}\end{array}$ & Species & $1997^{2}$ & $\begin{array}{l}\text { Present } \\
\text { study }\end{array}$ \\
\hline & & Order CYPRINIFORMES & & \\
\hline & & Family Cyprinidae & & \\
\hline 1 & $\mathrm{LC}$ & Barbodes banksi (Herre, 1940) & + & + \\
\hline 2 & NT & $\begin{array}{l}\text { Barbodes lateristriga (Valenciennes, in Cuvier \& } \\
\text { Valenciennes, 1842) }\end{array}$ & + & + \\
\hline 3 & $\mathrm{LC}$ & Cyprinus carpio (Linnaeus, 1758)*^ & - & + \\
\hline 4 & $\mathrm{LC}$ & Puntigrus tetrazona (Bleeker, 1855)* & + & + \\
\hline 5 & $\mathrm{LC}$ & Rasbora elegans Volz, 1903 & + & + \\
\hline 6 & $\mathrm{LC}$ & Rasbora einthovenii (Bleeker, 1851) & + & - \\
\hline \multirow[t]{3}{*}{7} & $\mathrm{LC}$ & Rasbora trilineata Steindachner, $1870 *$ & - & + \\
\hline & & Order SILURIFORMES & & \\
\hline & & Family Clariidae & & \\
\hline 8 & $\mathrm{LC}$ & Clarias batrachus (Linnaeus, 1758) & - & + \\
\hline 9 & $\mathrm{LC}$ & Clarias gariepinus (Burchell, 1822)*^ & - & + \\
\hline 10 & NT & Clarias leiacanthus Bleeker, 1851 & + & + \\
\hline \multirow[t]{3}{*}{11} & $\mathbf{C R}^{\#}$ & $\begin{array}{l}\text { Clarias nieuhofii Valenciennes, in Cuvier \& Valenciennes, } \\
1840\end{array}$ & - & + \\
\hline & & Order BELONIFORMES & & \\
\hline & & Family Zenarchopteridae & & \\
\hline \multirow[t]{3}{*}{12} & $\mathrm{LC}$ & Dermogenys collettei Meisner, 2001 & + & - \\
\hline & & Order CYPRINODONTIFORMES & & \\
\hline & & Family Aplocheilidae & & \\
\hline \multirow[t]{2}{*}{13} & $\mathrm{LC}$ & Aplocheilus armatus (Hasselt, 1823) & + & + \\
\hline & & Family Poeciliidae & & \\
\hline 14 & $\mathrm{LC}$ & Gambusia affinis (Baird \& Girard, 1853)* & - & + \\
\hline 15 & $\mathrm{LC}$ & Poecilia reticulata (Peters, 1859)* & + & + \\
\hline 16 & $\mathrm{LC}$ & Poecilia sphenops (Valenciennes, 1846)* & - & + \\
\hline 17 & $\mathrm{LC}$ & Xiphophorus maculatus (Günther, 1866)* & - & + \\
\hline
\end{tabular}


Table 1. Continuation.

\begin{tabular}{|c|c|c|c|c|}
\hline No. & $\begin{array}{l}\text { Local } \\
\text { Status } 1\end{array}$ & Species & $1997^{2}$ & $\begin{array}{l}\text { Present } \\
\text { study }\end{array}$ \\
\hline & & Order SYNBRANCHIFORMES & & \\
\hline & & Family Synbranchidae & & \\
\hline \multirow[t]{3}{*}{18} & $\mathrm{LC}$ & Monopterus javanensis La Cepède, 1800 & + & + \\
\hline & & Order PERCIFORMES & & \\
\hline & & Family Nandidae & & \\
\hline \multirow[t]{2}{*}{19} & $\mathbf{C R}^{\#}$ & Nandus nebulosus (Gray, 1835) & + & + \\
\hline & & Family Cichlidae & & \\
\hline 20 & $\mathrm{LC}$ & Mayaheros urophthalmum (Günther, 1862)*^ & - & + \\
\hline \multirow[t]{2}{*}{21} & $\mathrm{LC}$ & Oreochromis mossambicus (Peters, 1852)*^ & - & + \\
\hline & & Family Eleotridae & & \\
\hline \multirow[t]{2}{*}{22} & $\mathrm{LC}$ & Oxyeleotris marmorata (Bleeker, 1852) & + & + \\
\hline & & Family Anabantidae & & \\
\hline \multirow[t]{2}{*}{23} & $\mathrm{LC}$ & Anabas testudineus (Bloch, 1792) & + & - \\
\hline & & Family Osphronemidae & & \\
\hline 24 & $\mathrm{LC}$ & Betta pugnax (Cantor, 1849) & + & + \\
\hline 25 & $\mathrm{LC}$ & Osphronemus laticlavius Roberts, $1992 * \wedge$ & - & + \\
\hline 26 & $\mathrm{LC}$ & Trichopodus trichopterus (Pallas, 1770) & + & + \\
\hline \multirow[t]{2}{*}{27} & $\mathrm{LC}$ & Trichopsis vittata (Cuvier, in Cuvier \& Valenciennes, 1831) & + & + \\
\hline & & Family Channidae & & \\
\hline 28 & $\mathbf{C R}^{\#}$ & Channa gachua (Hamilton, 1822) & + & - \\
\hline 29 & NT & Channa lucius (Cuvier, in Cuvier \& Valenciennes, 1831) & + & + \\
\hline 30 & $\mathbf{C R}^{\#}$ & Channa melasoma (Bleeker, 1851) & - & + \\
\hline 31 & $\mathrm{LC}$ & Channa striata (Bloch, 1793) & + & + \\
\hline
\end{tabular}

${ }^{1}$ Local status in BTNR

${ }^{2}$ Records from Ng \& Lim (1997)

\#Conservation status partly following Lim et al. (2008)

*Introduced species

${ }^{\wedge}$ Species only recorded from the Singapore Quarry

+/-Presence/absence 

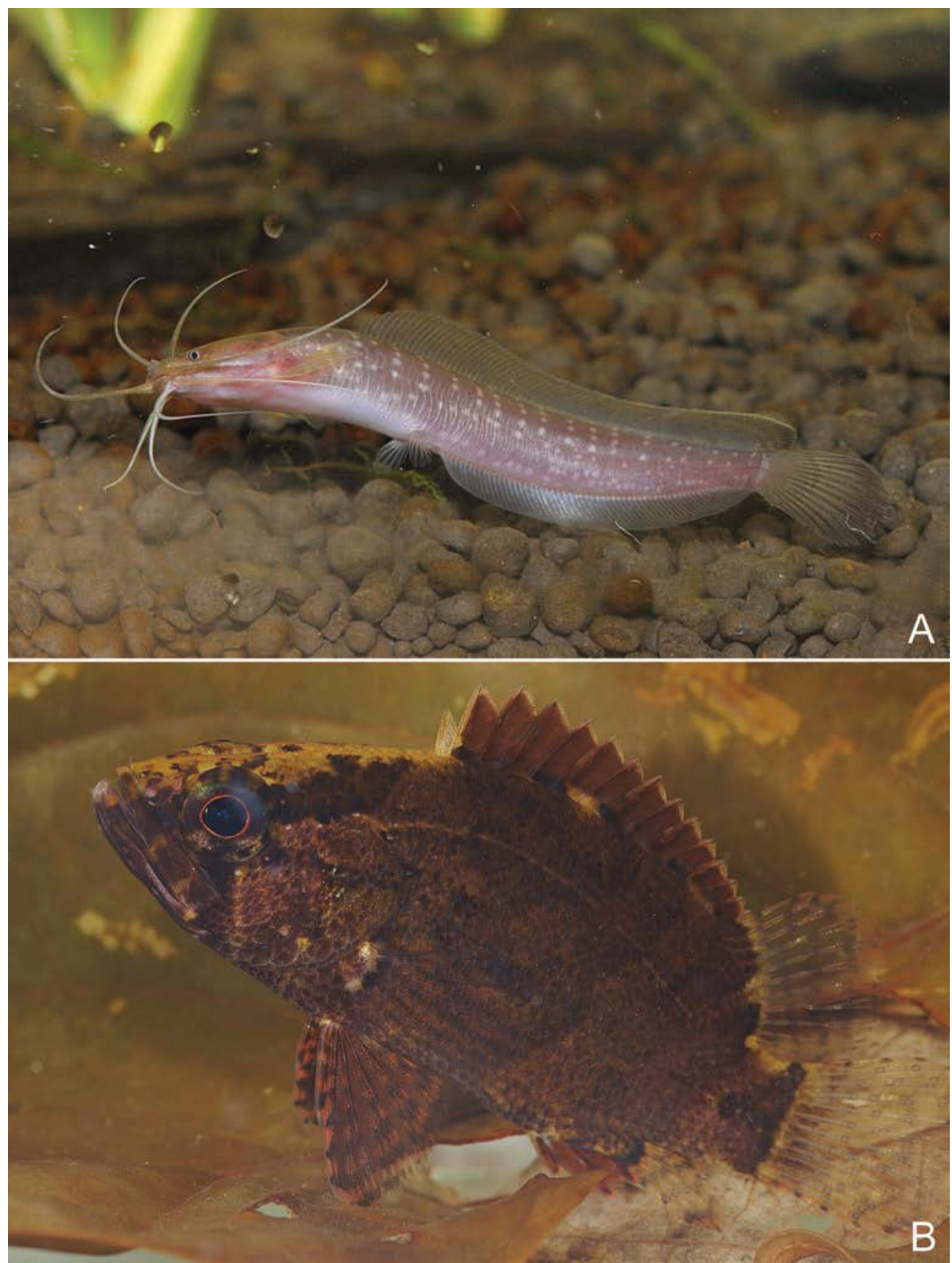

Fig. 3. Locally critically endangered fishes in BTNR. A. Slender walking catfish Clarias nieuhofii. B. Sunda leaf-fish Nandus nebulosus. (Photos: Y. Cai) 
Table 2. Distribution and mean abundance of freshwater fish at six main stream sampling sites in Bukit Timah Nature Reserve. Abbreviations: ++++: Abundant (>10.00), +++: Common (5.0110.00), ++: Uncommon (1.01-5.00), +: Rare (0.14-1.00), -: Not Found at site, ${ }^{*}$ represents introduced species.

\begin{tabular}{|c|c|c|c|c|c|c|}
\hline Species & $\begin{array}{c}\text { Stream } \\
1\end{array}$ & $\begin{array}{c}\text { Stream } \\
\quad 2\end{array}$ & $\begin{array}{l}\text { Stream } \\
3 \text { Pond }\end{array}$ & $\begin{array}{l}\text { Stream } \\
\quad 4\end{array}$ & $\begin{array}{c}\text { Stream } \\
\mathbf{5}\end{array}$ & $\begin{array}{l}\text { Stream } \\
6 \text { Pond }\end{array}$ \\
\hline \multicolumn{7}{|l|}{ Family Cyprinidae } \\
\hline Barbodes banksi & - & - & ++ & - & - & ++++ \\
\hline Puntigrus tetrazona* & - & - & ++++ & - & - & - \\
\hline Rasbora elegans & - & - & ++++ & - & - & - \\
\hline Rasbora trilineata* & - & - & ++++ & - & - & - \\
\hline \multicolumn{7}{|l|}{ Family Clariidae } \\
\hline Clarias leiacanthus & - & ++ & + & - & - & - \\
\hline Clarias nieuhofii & - & + & - & - & - & - \\
\hline \multicolumn{7}{|l|}{ Family Aplocheilidae } \\
\hline Aplocheilus armatus & - & - & ++ & - & - & - \\
\hline \multicolumn{7}{|l|}{ Family Poeciliidae } \\
\hline Gambusia affinis* & +++ & ++++ & - & - & - & ++ \\
\hline Poecilia reticulata* & +++ & ++++ & - & - & - & +++ \\
\hline Poecilia sphenops* & - & - & - & - & - & + \\
\hline Xiphophorus maculatus* & - & - & - & - & - & ++++ \\
\hline \multicolumn{7}{|l|}{ Family Synbranchidae } \\
\hline Monopterus javanensis & + & - & + & - & - & - \\
\hline \multicolumn{7}{|l|}{ Family Nandidae } \\
\hline Nandus nebulosus & - & - & + & - & - & - \\
\hline \multicolumn{7}{|l|}{ Family Osphronemidae } \\
\hline Betta pugnax & ++++ & ++++ & +++ & ++++ & ++++ & ++++ \\
\hline Trichopsis vittata & - & - & +++ & - & - & - \\
\hline \multicolumn{7}{|l|}{ Family Channidae } \\
\hline Channa lucius & - & - & + & - & - & - \\
\hline
\end{tabular}


Table 3. Distribution of freshwater fish at additional sampling sites in Bukit Timah Nature Reserve. Abbreviations: +: Presence, -: Absence, SQ: Singapore Quarry, * represents introduced species.

\begin{tabular}{|c|c|c|c|c|c|c|c|}
\hline Species & $\begin{array}{c}\text { Stream } \\
7\end{array}$ & $\begin{array}{c}\text { Stream } \\
8\end{array}$ & $\begin{array}{c}\text { Stream } \\
9\end{array}$ & $\begin{array}{c}\text { Stream } \\
10\end{array}$ & $\begin{array}{c}\text { Stream } \\
11\end{array}$ & $\begin{array}{c}\text { Stream } \\
12\end{array}$ & SQ \\
\hline \multicolumn{8}{|l|}{ Family Cyprinidae } \\
\hline Barbodes lateristriga & - & - & - & - & - & - & + \\
\hline Cyprinus carpio* & - & - & - & - & - & - & + \\
\hline \multicolumn{8}{|l|}{ Family Clariidae } \\
\hline Clarias batrachus & + & - & - & + & + & - & - \\
\hline Clarias gariepinus & - & - & - & - & - & - & + \\
\hline \multicolumn{8}{|l|}{ Family Poeciliidae } \\
\hline Gambusia affinis* & - & - & + & - & + & - & + \\
\hline Poecilia reticulata* & - & - & + & + & + & + & - \\
\hline \multicolumn{8}{|l|}{ Family Synbranchidae } \\
\hline Monopterus javanensis & + & - & - & - & - & - & - \\
\hline \multicolumn{8}{|l|}{ Family Cichlidae } \\
\hline Mayaheros uropthalmum* & - & - & - & - & - & - & + \\
\hline Oreochromis mossambicus* & - & - & - & - & - & - & + \\
\hline \multicolumn{8}{|l|}{ Family Eleotridae } \\
\hline Oxyeleotris marmorata & - & - & - & - & - & - & + \\
\hline \multicolumn{8}{|l|}{ Family Osphronemidae } \\
\hline Betta pugnax & + & - & + & - & - & - & - \\
\hline Osphronemus laticlavius & - & - & - & - & - & - & + \\
\hline Trichopodus trichopterus & - & - & - & - & - & - & + \\
\hline \multicolumn{8}{|l|}{ Family Channidae } \\
\hline Channa striata & - & - & - & - & - & - & + \\
\hline
\end{tabular}

\section{Discussion}

Species diversity and distribution of freshwater fish in BTNR

As the last in-depth biodiversity assessment of aquatic fauna in BTNR was conducted more than two decades ago (Lim, 1995; Ng \& Lim, 1997), results from the current survey are useful in addressing gaps in knowledge and highlighting new 


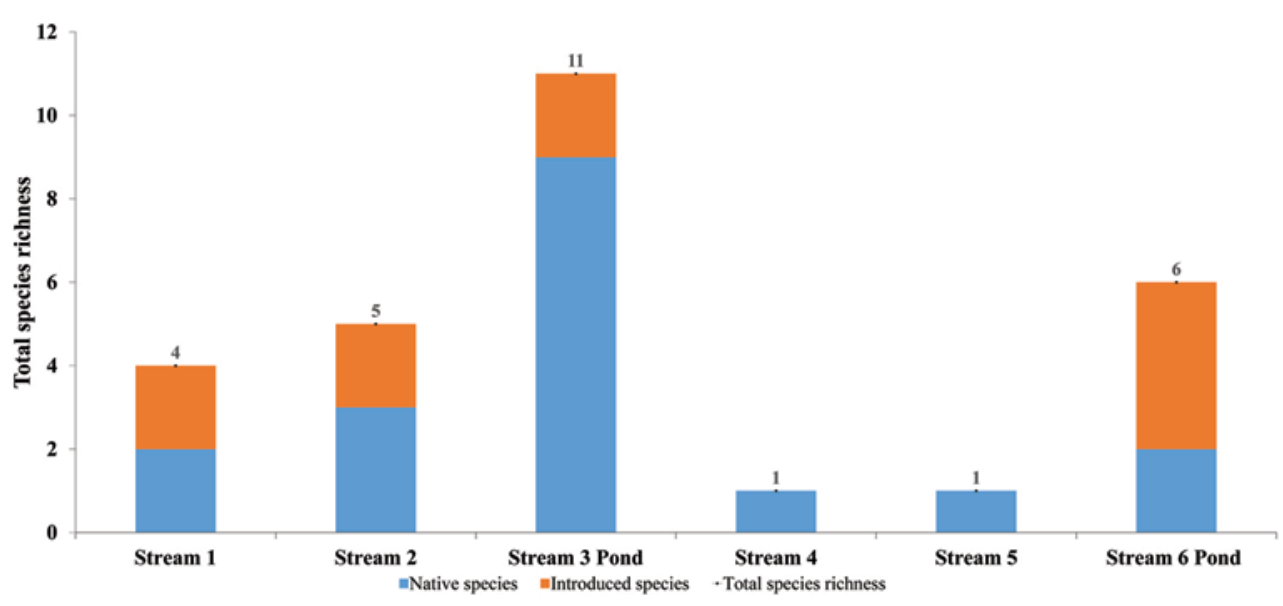

Fig. 4. Total Species Richness of freshwater fish at six main sampling sites.

discoveries. This is exemplified by the discovery of a new site locality at the eastern side of BTNR for the Singapore freshwater crab Johora singaporensis (Li et al., 2015) and Yellow-banded caecilian Ichthyophis paucisulcus (Lim et al., 2015).

Through the course of the survey, 27 species of freshwater fish have been documented. Among these, three species were listed in the Singapore Red Data Book as critically endangered. Some species documented in past studies were not recorded in the current survey, including Rasbora einthovenii, Dermogenys collettei, Anabas testudineus and Channa gachua. These species were previously found only in the pond draining Stream 3, which was physically challenging to survey thoroughly due to its large size and deep waters, hence possibly resulting in missing species.

More importantly, this study resulted in the addition of two new native species Clarias batrachus and Clarias nieuhofii, which were not reported by $\mathrm{Ng} \&$ Lim (1997). Clarias nieuhofii is an uncommon catfish which inhabits heavily shaded forest streams with acidic water and is known to be present only in the Central Catchment Nature Reserve (CCNR) within mainland Singapore (Baker \& Lim, 2012; Li et al., 2016). Although this species is primarily found in forest streams with $\mathrm{pH}$ 4.5-5.0 (Li et al., 2016), there was also a record of the fish from Upper Seletar Reservoir Park at the forest edge (Lim, 2013b), which suggests some tolerance to fluctuating $\mathrm{pH}$ levels and urban conditions. Stream 2 in BTNR has similar habitat parameters (acidic water, thick leaf litter) as the sites in CCNR where Clarias nieuhofii was previously recorded, which might explain its presence in BTNR. Clarias batrachus is the most widespread native catfish in Singapore found in both forest and urban areas as it is able to tolerate disturbed and exposed habitats although it has declined significantly since the introduction of the African Clarias gariepinus $(\mathrm{Ng}$ et al., 2013). Within BTNR, Clarias batrachus is recorded mainly from streams at the periphery. This study also confirmed that the critically endangered Sunda leaf-fish Nandus nebulosus, documented in Ng \& Lim (1997), is still present in BTNR. This rare species inhabits slow-flowing and well-shaded streams and can be very hard to 
Table 4. Water parameters at the six main sampling sites in Bukit Timah Nature Reserve. *denotes ponds draining the streams.

\begin{tabular}{llll}
\hline Stream & Mean pH & Mean Temp. $\left[{ }^{\circ} \mathbf{C}\right]$ & Mean Dissolved Oxygen $[\mathbf{p p m}]$ \\
\hline 1 & 5.67 & 25.47 & 6.90 \\
2 & 5.88 & 26.03 & 5.13 \\
$3^{*}$ & 5.94 & 26.98 & 3.52 \\
4 & 4.28 & 25.84 & 4.65 \\
5 & 4.78 & 25.86 & 3.82 \\
$6 *$ & 5.94 & 26.59 & 2.55 \\
\hline
\end{tabular}

spot due to its cryptic coloration and behaviour. The pond draining Stream 3 currently appears to be the only locality of this fish outside CCNR.

The pond draining Stream 3 at the eastern side of BTNR had the highest freshwater fish species richness. This pond is approximately $30 \mathrm{~m}$ across. Abundant riparian vegetation flanks the banks of the deep pond (c. $>2 \mathrm{~m}$ ) and water flow is very slow. The muddy and uneven substratum and aquatic vegetation (algae, moss and epiphytes) serve to create a variety of microhabitats for different aquatic organisms, which could account for the relatively high species richness. The open canopy, and the less acidic and relatively sluggish water attract a large number of pond-loving odonates, e.g., Banded Skimmer Pseudothemis jorina and Orange-striped Threadtail Prodasineura humeralis, which were also observed to be actively breeding at this site (Cai et al., 2019). The presence of four native piscine predators (three Channa species and Nandus nebulosus) at this site suggests a complex community with sufficient prey to support them. Only one species of freshwater fish, Betta pugnax, was recorded from Streams 4 and 5 throughout the survey period. There are somewhat acidic water conditions at these sites ( $\mathrm{pH} 4.28-4.78)$, with a very thick, muddy streambed and low dissolved oxygen levels, which are unfavourable to many aquatic species. The high acidity in Streams 4 and 5 might be due to leaching of tannins from decomposing leaf litter (Deano \& Robinson, 2008), or other factors such as acid rain (Balasubramanian et al., 2001; Zhong et al., 2001). The muddy substratum and dense leaf litter also supported a population of the endemic Johnson's freshwater crab Irmengardia johnsoni (see Khoo et al., 2019). This demonstrates the need for different specific habitat/microhabitats, which are not necessarily always found in the same area (e.g., in the same stream). Hence, conservation efforts should focus on the entire stream network in BTNR and not in isolated pockets. 
Introduced species

A total of 11 introduced species were found, including Clarias gariepinus, Cyprinus carpio, Mayaheros urophthalmum, Oreochromis mossambicus, Osphronemus laticlavius, Gambusia affinis, Poecilia reticulata, Poecilia sphenops, Xiphophorus maculatus, Puntigrus tetrazona and Rasbora trilineata. The first five species are restricted to Singapore Quarry while the last two species were found only in the pond draining Stream 3. Many of these species are likely to have originated from the ornamental pet trade (Yeo \& Chia, 2010; Ng \& Tan, 2010; Lim 2013a). This pond is easily accessible to the public via an open trail from Rifle Range Road, which likely provided ample opportunities for illegal release of unwanted ornamental fishes. It is also possible that these species may have originated from ornamental or food fishes kept in villages (or "kampungs") that were once present around the periphery of BTNR. Large populations of scissortail rasbora, Rasbora trilineata, and four-banded tiger barb, Puntigrus tetrazona, have been observed to inhabit the pond, which is also highly likely to be the sole locality of the former species in Singapore according to published records (Lim \& Tan, 2011). The introduced freshwater shrimp, Macrobrachium lanchesteri, which declined in population in the 1990s, was also recorded from this site (Yeo, 2010; see Khoo et al., 2019). The open and exposed Singapore Quarry at the western side of BTNR also supports large populations of introduced species dominated by cichlids and carps, again likely due to its high accessibility by the public, and also its large size. Interestingly, the Giant gouramy Osphronemus goramy, which is a common species in the aquarium trade, was not recorded in the current study and its distribution seems to be restricted to MacRitchie Reservoir and Bedok Reservoir (Ng \& Tan, 2010). Large populations of Gambusia affinis, Poecilia reticulata and Xiphophorus maculatus were present in the streams at the periphery of BTNR and most of these streams are concretised at the lower reaches due to urban development. The higher $\mathrm{pH}$, broken canopy and shallow water in these areas are more suitable for these introduced species which can tolerate such harsh environmental conditions, as opposed to native freshwater species which prefer shaded forest streams (Ng \& Tan, 2010; Baker \& Lim, 2012; Kwik \& Yeo, 2015).

\section{Recommendations and conclusion}

Important aspects of the freshwater fish communities of streams in BTNR, such as distribution, species richness and species abundance, have been documented in this survey, and these results will serve as important baseline data for further studies. Comparison of the results with records from previous studies shows that while there seems to be some species turnover (i.e., differences in species composition), the overall native fish diversity has not changed much in the past twenty years. This shows that BTNR remains a key conservation area for freshwater fauna and an important sanctuary for threatened native biodiversity. Being a nature reserve, BTNR is currently under legal protection by Singapore's National Parks Act (Cap. 198A) and Parks and Trees Act (2005). However, the area is still facing threats from changing hydrological 
regimes, invasion of introduced species at the outskirts and potential developments at the peripheries. It is evident from the survey that introduced fish species have increased in both diversity and abundance in the past twenty years. A more pressing issue is the acidification of the streams in BTNR for reasons yet unknown, especially in the core regions, which can lead to a reduction in the diversity of freshwater fauna in the long run (Feldman \& Connor, 1992; Courtney \& Clements, 1998). While the $\mathrm{pH}$ of these streams was 5-6 in the 1960s (Ong, 1965), it had dropped to 4.5 in 2014 and has remained so since. The low acidity of these streams had been attributed to precipitation bringing in compounds from the decomposition of leaf litter, by surface wash, which was suggested as a possible factor in the extirpation of the endemic freshwater crab Johora singaporensis from its original type locality at Stream $4(\mathrm{Ng}$ et al., 2014). On the other hand, a new site locality for Johora singaporensis (Li et al., 2015; Khoo et al., 2019) was discovered recently. More well-designed ecological research studies need to be conducted to determine and ascertain the key factors that lead to the change in water conditions, hence affecting the composition of the freshwater communities.

Where possible, mitigation measures should be implemented to prevent further invasion of the introduced species. Recommendations include provision of more resources for monitoring and physical removal of the introduced species on a regular basis and for enforcement against illegal release of unwanted pets in the nature reserve. Enhancing riparian vegetation along the banks of streams in the periphery can help to minimise bank erosion and lower the water temperature, while retaining woody debris in the streams contributes to preserving the natural habitat of the native species, providing a more suitable environment for the natives over introduced species which generally prefer disturbed habitats. It is hearty to note that there is an existing system which imposes stringent screening criteria on developers, implements Environmental Impact Assessments (EIA), as well as Environmental Management and Monitoring Plans (EMMP), on proposed developments at the outskirts of the nature reserve to ensure that developments are processed in an ecologically sensitive manner. This practice should continue in the long run as it is prudent for the conservation of our natural heritage.

For the long-term survival of fish fauna of BTNR, the holistic approach of the closure of BTNR is very important as all the headwaters and the natural stretches of these streams lie within in BTNR (Cai, 2019; Nguyen \& Cai, 2019). The benefits of the recent closure of BTNR to the restoration of the streams attest to this.

The information from this study should be useful in updating the status of freshwater fish in BTNR and can be used in the formulation of conservation measures and establishment of monitoring programs for the protection of our native and threatened fauna in BTNR in the future.

ACKNOWLEDGEMENTS. We would like to thank Lena Chan and Geoffrey Davison for their support, Yvonne Nga, Nigel Tiong, Audrey Lee for helping out in field surveys, and Daniel $\mathrm{Ng}$ for discussion. This study forms part of the Bukit Timah Nature Reserve Comprehensive Survey funded by National Parks Board. 


\section{References}

Baker, N. (2014). Black snakeheads at Bukit Timah Nature Reserve. Singapore Biod. Rec. 2014: 273.

Baker, N. \& Lim, K.K.P. (2012). Wild Animals of Singapore: A Photographic Guide to Mammals, Reptiles, Amphibians and Freshwater Fishes. Updated Edition. Singapore: Draco Publishing and Distribution Pte. Ltd. and Nature Society (Singapore), 180 pp.

Balasubramanian, R., Victor, T. \& Chun, N. (2001). Chemical and Statistical Analysis of Precipitation in Singapore. Water, Air, and Soil Pollution 130: 451-456.

Cai, Y. Nga, Y.P.Q. \& Ngiam, R.W.J. (2019). Dragonflies of Bukit Timah Nature Reserve, Singapore. Gard. Bull. Singapore 71 (Suppl. 1): 293-316.

Chan, L. \& Davison, G.W.H. (2019). Introduction to the Comprehensive Biodiversity Survey of Bukit Timah Nature Reserve, Singapore, 2014-2018. Gard. Bull. Singapore 71 (Suppl. 1): 3-17.

Chua, W.J., Ng, D.J.J., Zeng, Y. \& Yeo, D.C.J. (2015). Habitat characteristics of tropical rainforest freshwater crabs (Decapoda: Brachyura: Potamidae, Gecarcinucidae). J. Crust. Biol. 35(4): 53-56.

Courtney, L.A. \& Clements, W.H. (1998). Effects of acidic pH on benthic macroinvertebrate communities in stream microcosms. Hydrobiologia 379: 135-145.

Deano, P.M. \& Robinson, J.W. (2008). The effect of decaying leaves on the PH and buffer capacity of waters. Journal of Enviromental Science and Health. Part A: Environmental Science and Engineering, 20(8): 903-911.

Feldman, R.S. \& Connor, E.F. (1992). The relationship between $\mathrm{pH}$ and community structure of invertebrates in streams of the Shenadoah National Park, Virginia, USA. Freshwater Biology 27: 261-276.

Khoo, M.D.Y., Tiong, N.J.L., Li, T., Lim, W., Ng, D.J.J., Nyanasengeran, M., Yeo, D. C. J. \& Cai, Y. (2019). The freshwater decapod crustaceans of Bukit Timah Nature Reserve, Singapore. Gard. Bull. Singapore 71 (Suppl. 1): 575-581.

Kwik, J.T.B. \& Yeo, D.C.J. (2015). Differences in fish assembl ages in protected and non-protected freshwater streams in a tropical urbanized country. Hydrobiologia 762(1): $143-156$.

Li, T.J., Lim, W.H. \& Cai, Y. (2015). A new locality of the Singapore Freshwater Crab Johora singaporensis (Crustacea: Brachyura: Potamidae) in the Bukit Timah Nature Reserve. Nature in Singapore 8: 53-56.

Li, T. J., Chay, C. K., Lim, W. H. \& Cai, Y. (2016). The fish fauna of Nee Soon Swamp Forest, Singapore. Raffles Bull. Zool. (Suppl. 32): 56-84.

Lim, K.K.P. (1995). Chapter 14. Fishes. In: Chin, S. C., Corlett, R. T., Wee, Y. C., \& Geh, S. Y. (eds.) Rain Forest in the City: Bukit Timah Nature Reserve, Singapore. Gard. Bull. Singapore. (Suppl. 3):159-163.

Lim, K.K.P. (2013a). Red giant gouramy at Singapore Quarry. Singapore Biodiversity Records. 2013: 7.

Lim, K.K.P. (2013b) Two syntopic walking catfishes at Upper Seletar. Singapore Biodiversity Records 2013: 92-93.

Lim, K.K.P. \& Tan, H.H. (2011). Addition of three cyprinid fishes to the established alien fauna of Singapore. Nature in Singapore 4: 377-382.

Lim, K.K.P., Tan, H.H. \& Low, J.K.Y. (2008). Fishes. In: Davison, G.W.H., Ng, P.K.L. \& Ho, H.C. (eds.) The Singapore Red Data Book. Second Edition. Singapore: Nature Society (Singapore), pp. 213-244. 
Lim, W.H., Li, T. J. \& Cai, Y. (2015). A new locality in Singapore for the caecilian, Ichthyophis paucisulcus. Nature in Singapore 8: 73-75.

Ng, D.J.J., Yeo, D.C.J., Sivasothi, N. \& Ng, P.K. L. (2014). Conservation challenges and action for the critically endangered Singapore freshwater crab Johora singaporensis. Oryx 49: 345-351.

Ng, H. H. \& Tan, H. H. (2010). An annotated checklist of the non-native freshwater fish species in the reservoirs of Singapore. Cosmos 6(1): 95-116.

Ng, H. H., Low, B. W., Kwik, J. T. B. \& Yeo, D. C. J. (2013). The tables are turned: an invasive species under potential threat. Biological Invasions 16(8): 1567-1571.

Ng, P.K.L. \& Lim, K.K.P. (1997). The diversity and conservation status of fishes in the nature reserves of Singapore. Gard. Bull. Singapore 49: 245-265.

Nguyen, C.T.T. \& Cai, Y. (2019) Physicochemical characteristics of streams in Bukit Timah Nature Reserve, Singapore. Gard. Bull. Singapore 71 (Suppl. 1): 491-556.

Ong, K.M. (1965). A faunal study of a stream on Bukit Timah Hill. BSc. Thesis. Singapore: Department of Zoology, National University of Singapore.

Tan, H.H., Yeo, D.C.J., Low, B.W. \& Nyanasengeran, M. (2017). Fishes, shrimps and aquatic molluscs observed at Singapore Quarry. Singapore Biodiversity Records 2017: 7-9.

Yeo, D.C.J. (2010). Introduced decapod crustaceans in Singapore's reservoirs. Cosmos 6(1): $85-100$.

Yeo, D.C.J. \& Chia, C.S.W. (2010). Introduced species in Singapore: an overview. Cosmos 6(1): 23-37.

Zhong, Z.C., Victor, T. \& Balasubramanian, R. (2001). Measurement of major organic acids in rainwater in Southeast Asia during burning and non-burning periods. Water, Air, and Soil Pollution 130: 457-462. 